$$
\begin{aligned}
& \text { CONF- } 9606238--1 \\
& \text { SANO96-1729C }
\end{aligned}
$$

\title{
SYNTHESIS AND PROCESSING OF COMPOSITES BY REACTIVE METAL PENETRATION
}

\author{
Ronald E. Loehman and Kevin G. Ewsuk \\ Sandia National Laboratories \\ Albuquerque, New Mexico 87185 \\ Antoni P. Tomsia \\ Pask Research and Engineering \\ Berkeley, California 94720 \\ William G. Fahrenholtz \\ University of New Mexico \\ Albuquerque, NM 87106
}

\begin{abstract}
When molten aluminum is placed in contact with a dense mullite preform it infiltrates the ceramic and converts it to a composite. Analysis showed that their composite consisted of a cocontinuous network of $\mathrm{Al}_{2} \mathrm{O}_{3}$ ceramic and $\mathrm{Al}-\mathrm{Si}$ alloy. Further work revealed that this technique is a general route to composite synthesis with the prospect for near-net-shape processing.

Generally, reactions between $\mathrm{Al}$ and oxides are of the form;

$$
(2+\mathrm{x}) \mathrm{Al}+(3 / \mathrm{y}) \mathrm{MO}_{\mathrm{y}} \rightarrow \mathrm{Al}_{2} \mathrm{O}_{3}+\mathrm{Al}_{\mathrm{x}} \mathrm{M}_{3 / \mathrm{y}}
$$

where $\mathrm{MO}_{\mathrm{y}}$ can be either a simple binary or complex oxide, and the residual metal phase can take a variety of forms as deternined by the phase equilibrium relations of the given system. Reactive penetration has been found in a number of oxide-metal systems for which there is both favorable wetting of the oxide by the molten metal (i.e., contact angle $\theta<90^{\circ}$ ) and a negative Gibbs energy for reaction.

In the $\mathrm{A} V$ mullite system, molten aluminum reduces mutlite to produce alumina and elemental silicon according to the reaction,

$$
3 \mathrm{Al}_{6} \mathrm{Si}_{2} \mathrm{O}_{13}+(8+x) \mathrm{Al} \rightarrow 13 \mathrm{Al}_{2} \mathrm{O}_{3}+6 \mathrm{Si}+x \mathrm{Al}
$$

For the reaction with $x=0, \Delta G_{r}(1200 \mathrm{~K})=-1014 \mathrm{~kJ}$ and $\Delta G_{r}(1600 \mathrm{~K})=-828 \mathrm{~kJ}$.

With excess aluminum present (i.e., $x>0$ ), a composite of alumina, silicon, and aluminum is formed. When the mullite preform is in contact with a large external source of molten $\mathrm{Al}$, the $\mathrm{Si}$ produced from the reaction diffuses outward into the Al source, leaving only a small concentration in the composite. Thus, the process naturally avoids leaving significant amounts of Si that could embrittle the composite.

Metal-ceramic composites have been produced by reactive penetration of dense and porous ceramic preforms with molten metal and by reactive sintering or hot pressing mixtures of ceramic and metal powders. Experimental results on different compositions of metal-ceramic reaction couples indicate that reactive metal penetration can be a general route to composite synthesis. Additionally, in many systems, reactive metal penetration affords near-net-shape forming capability. Because composite formation by reactive metal penetration appears to be a
\end{abstract}

\section{DISTRISUTION OF THIS DOCUMENT IS UMLMIED}

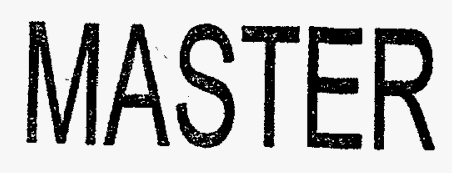

This wok yos suported by the United

States Deperiment of Enery under

Contrict DE-ACN4-91AL85000. 
diffusion controlled process with parabolic reaction kinetics at short times, metal-ceramic composite coatings can be made by controlling the penetration time.

Making composites with physical properties optimized for particular applications is one of the potential benefits of the reactive metal penetration process. For composites in the $\mathrm{Al} / \mathrm{Si} / \mathrm{Al}_{2} \mathrm{O}_{3}$ system, improvements in Young's modulus, fracture strength, density, hardness, fracture toughness, and specific modulus are apparent as compared with the pure mullite preform. The fracture toughness of reactively-formed metal-ceramic composites increases with increasing Al concentration, while modulus and density remain relatively constant, making it possible to make materials that are both tough and have a high specific modulus (i.e., modulus/density). Mechanical and physical property data, as well as microstructural evidence, indicate a three-dimensional, alumina skeletal structure is formed during reactive penetration. For higher Al concentrations the $\mathrm{Al}$ phase also is continuous, resulting in a composite with mutuallyinterpenetrating metal and ceramic phases. Results also indicate that, relative to the ceramic preform, the composites are more flaw tolerant; that is, the strength degradation from crack formation and propagation appears to be less severe in the metal-ceramic composite than in the mullite preform.

With further development, improvements in strength and fracture toughness can be expected.

\section{Properties of Metal-Ceramic Composites Formed by Reactive Metal Penetration Compared to the Properties of the Ceramic Preform}

\section{Property}

Bend Strength(MPa)

Hardness (GPa)

Toughness $(\mathrm{MPa} \cdot \sqrt{\mathrm{m}})$

Density (g/cc)

Young's Modulus (GPa)

Specific Modulus(GPa-cm3/g)

\begin{tabular}{c} 
Mullite \\
\hline 180 \\
11.2 \\
1.7 \\
3.16 \\
200 \\
63
\end{tabular}

$\mathrm{Al}_{2} \mathrm{O}_{3}-\mathrm{Al}-\mathrm{Si}$ Composite

250-320

10-11

6-9

3.6

274

76-86 


\title{
SYNTHESIS AND PROCESSING OF COMPOSITES BY REACTIVE METAL PENETRATION
}

\author{
Ronald E. Loehman and Kevin G. Ewsuk \\ Sandia National Laboratories \\ Albuquerque, New Mexico 87185 \\ Antoni P. Tomsia \\ Pask Research and Engineering
Berkeley, California 94720 \\ Berkeley, California 94720 \\ William G. Fahrenholtz \\ University of New Mexico \\ Albuquerque, NM 87106
}

\section{INTRODUCTION}

Ceramic-metal composites are being developed as engineering materials because of their high stiffness-to-weight ratios, good fracture toughness, and because their electrical and thermal properties can be varied through control of their compositions and microstructures. Wider use of ceramic-metal composites requires improvements in synthesis and processing so that highperformance parts can be produced more economically. Over the past three years reactive metal penetration has been shown to be a promising technique for making ceramic and metal-matrix composites to near-net-shape with control of both composition and microstructure. It appears that reactive metal penetration could be an economical process for manufacturing many of the advanced ceramic composites that are needed for light-weight structural and wear applications for transportation and energy conversion devices. Near-net-shape fabrication of parts has the additional advantage that costly and energy intensive grinding and machining operations are significantly reduced, and the waste generated from such finishing operations is minimized.

The goals of this research and development program are: 1) to identify compositions favorable for making composites by reactive metal penetration; 2) to understand the mechanism(s) by which these composites are formed; and 3) to control and optimize the process so that composites and composite coatings can be made economically.

\section{TECHNICAL PROGRESS: FY 1995}

\section{Summary}

This work is based on the discovery by R.E. Loehman of SNL and A.P. Tomsia of Pask Research and Engineering that when molten aluminum is placed in contact with a dense mullite preform it infiltrates the ceramic and converts it to a composite. Analysis showed that their composite consisted of a co-continuous network of $\mathrm{Al}_{2} \mathrm{O}_{3}$ ceramic and $\mathrm{Al}-\mathrm{Si}$ alloy. Further work revealed that this technique is a general route to composite synthesis with the prospect for nearnet-shape processing.

Generally, reactions between $\mathrm{Al}$ and oxides are of the form;

$$
(2+x) \mathrm{Al}+(3 / \mathrm{y}) \mathrm{MO}_{\mathrm{y}} \rightarrow \mathrm{Al}_{2} \mathrm{O}_{3}+\mathrm{Al}_{\mathrm{x}} \mathrm{M}_{3 / \mathrm{y}}
$$


where $\mathrm{MO}_{\mathrm{y}}$ can be either a simple binary or complex oxide, and the residual metal phase can take a variety of forms as determined by the phase equilibrium relations of the given system. Reactive penetration has been shown to produce composites in a number of oxide-metal systems for which there is both favorable wetting of the oxide by the molten metal (i.e., contact angle $\theta<$ $90^{\circ}$ ) and a negative Gibbs energy for reaction.

In the $\mathrm{Al} /$ mullite system, molten aluminum reduces mullite to produce alumina and elemental silicon according to the reaction,

$$
3 \mathrm{Al}_{6} \mathrm{Si}_{2} \mathrm{O}_{13}+(8+\mathrm{x}) \mathrm{Al} \rightarrow 13 \mathrm{Al}_{2} \mathrm{O}_{3}+6 \mathrm{Si}+\mathrm{x} \mathrm{Al}
$$

For the reaction with $\mathrm{x}=0, \Delta \mathrm{G}_{\mathrm{r}}(1200 \mathrm{~K})=-1014 \mathrm{~kJ}$ and $\Delta \mathrm{G}_{\mathrm{r}}(1600 \mathrm{~K})=-828 \mathrm{~kJ}$.

With excess aluminum present (i.e., $x>0$ ), a composite of alumina, silicon, and aluminum is formed. When the mullite preform is in contact with a large external source of molten $\mathrm{Al}, \mathrm{the} \mathrm{Si}$ produced from the reaction diffuses outward into the Al source, leaving only a small concentration in the composite. Thus, the process naturally avoids leaving significant amounts of Si that could embrittle the composite.

Ceramic-metal composites have been produced by reactive penetration of dense and porous ceramic preforms with molten metal and by reactive sintering or hot pressing mixtures of ceramic and metal powders. Experimental results on different compositions of ceramic-metal reaction couples indicate that reactive metal penetration can be a general route to composite synthesis. Additionally, in many systems, reactive metal penetration affords near-net-shape forming capability. Ceramic-metal composite coatings can be made by controlling the penetration time.

Making composites with physical properties optimized for particular applications is one of the potential benefits of the reactive metal penetration process. For composites in the $\mathrm{Al}_{2} \mathrm{O}_{3} / \mathrm{Al} / \mathrm{Si}$ system, improvements in Young's modulus, fracture strength, density, hardness, fracture toughness, and specific modulus are apparent as compared with the pure mullite preform, as shown in Table 1. The fracture toughness of reactively-formed ceramic-metal composites increases with increasing $\mathrm{Al}$ concentration, while modulus and density remain relatively constant, making it possible to make materials that are both tough and have a high specific modulus (i.e., modulus/density).

Table 1. Properties of Ceramic-Metal Composites Formed by Reactive Metal Penetration Compared to the Properties of the Ceramic Preform

\begin{tabular}{lcc}
\multicolumn{1}{c}{ Property } & Mullite & Al2 \\
Bend Strength $(\mathrm{MPa})$ & 180 & $250-320$ \\
Hardness $(\mathrm{GPa})$ & 11.2 & $10-11$ \\
Toughness $(\mathrm{MPa} \cdot \sqrt{\mathrm{m})}$ & 1.7 & $6-9$ \\
Density $(\mathrm{g} / \mathrm{cc})$ & 3.16 & 3.6 \\
Young's Modulus $(\mathrm{GPa})$ & 200 & 274 \\
Specific Modulus $\left(\mathrm{GPa} \cdot \mathrm{cm}^{3} / \mathrm{g}\right)$ & 63 & $76-86$
\end{tabular}


Mechanical and physical property data, as well as microstructural evidence, indicate a three-dimensional, alumina skeletal structure is formed during reactive penetration. For higher $\mathrm{Al}$ concentrations the Al phase also is continuous, resulting in a composite with mutuallyinterpenetrating metal and ceramic phases. Results also indicate that, relative to the ceramic preform, the composites are more flaw tolerant; that is, the strength degradation from crack formation and propagation appears to be less severe in the ceramic-metal composite than in the mullite preform. With further development, improvements in strength and fracture toughness can be expected.

\section{Milestones:}

Work this year has focused on Tasks 1,2, 3, and 5 of the Field Work Proposal.

Task 1. Evaluate Mechanisms of Composite Formation in the Al/Mullite System

We have continued our experiments to understand the mechanism for reactive metal penetration. By combining TEM results on microstructural development with previously obtained thermodynamics and kinetic data, we have been able to develop a likely reaction mechanism for reactive metal penetration. As reported previously, the concentration of oxygen in the system $\left(\mathrm{PO}_{2}\right)$ during reaction plays a critical role. At $1200 \mathrm{~K}$, there is a large thermodynamic driving force for reaction (2) to proceed as written (i.e., $\Delta \mathrm{G}_{\mathrm{r}}=-1014 \mathrm{~kJ}$ ). However, there is also a large thermodynamic driving force for reaction of aluminum with atmospheric oxygen to form alumina at $1200 \mathrm{~K}$ (i.e., $\Delta \mathrm{G}_{\mathrm{r}}=-1163 \mathrm{~kJ} / \mathrm{mole}$ ). The Ellingham diagram for $\mathrm{Al} / \mathrm{Al}_{2} \mathrm{O}_{3}$ indicates that $\mathrm{Al}$ and alumina will be in equilibrium at a $\mathrm{PO}_{2}$ of $10^{-28.5}$ atm., which is a condition favorable for wetting. Thus, to limit Al oxidation by atmospheric oxygen and to ensure the $\mathrm{Al} /$ mullite reaction proceeds as written in reaction (2), a system $\mathrm{P}_{2}$ of $\leq 10^{-28.5}$ atmospheres is required. It seems likely that the molten $\mathrm{Al}$ itself acts as an $\mathrm{O}_{2}$ getter during the reaction to reduce the $\mathrm{P}_{2}$ of the mullite grain boundaries to $\leq 10^{-28.5}$ atmospheres, which will make conditions favorable for wetting and reaction. The optically-visible reaction layer formed during partial penetration can be attributed to the localized oxygen deficiency and initial precipitation of metal particles at the grain boundaries. The time required to reduce grain boundary oxygen concentration to $\leq 10^{-28.5}$ atmospheres can explain the $5-10$ minute delay in penetration at the start of an experiment. Finally, localized grain boundary reduction also explains the difference in penetration of dense and porous mullite preforms. It appears that, because oxygen diffusion through an interconnected pore structure is faster than along grain boundaries, it is more difficult to achieve a favorable $\mathrm{PO}_{2}$ condition for wetting and reaction in a porous mullite body.

To characterize wetting and penetration in the $\mathrm{Al} /$ mullite system, sessile drop experiments were conducted with high purity, molten aluminum on dense mullite at 900,1000 , and $1100^{\circ} \mathrm{C}$. Contact angles decrease with time at $900^{\circ} \mathrm{C}$ and above. Because of metal penetration and reaction, the molten $\mathrm{Al}$ drop decreases in volume during the experiment. The absence of a steady-state contact angle is indicative of an on-going chemical reaction. XRD analysis shows the infiltrated specimens contain $\mathrm{Al}_{2} \mathrm{O}_{3}, \mathrm{Al}$, and, usually $\mathrm{Si}$, demonstrating that 
the reaction is the same whether the product is formed by reaction of mixed powders or by penetration of $\mathrm{Al}$ into the dense ceramic. Sessile drop experiments conducted on nominally $100 \%, 99.5 \%$, and $99 \%$ pure, dense mullite (with the remainder as $\mathrm{SiO}_{2}$ ) at $1100^{\circ} \mathrm{C}$ reveal no significant differences in wetting behavior with minor compositional variations in the ceramic preform. Wetting (i.e., $\theta<90^{\circ}$ ) is not observed at $900^{\circ} \mathrm{C}$ and it occurs only after $\sim 30$ minutes at $1000^{\circ} \mathrm{C}$ in the $\mathrm{Al} /$ mullite system. Aluminum penetration and composite formation are sluggish below $\sim 1000^{\circ} \mathrm{C}$, indicating that both wetting and a negative Gibbs energy of reaction are required to make ceramic-metal composites by reactive metal penetration.

To more quantitatively determine the kinetics of ceramic-metal composite formation in the $\mathrm{Al} /$ mullite system, an apparatus was designed and constructed for making ceramic-metal composites by controlled dipping of ceramic preforms in molten aluminum. Reaction times were accurately controlled by dipping a dense ceramic preform into molten aluminum at $900-1500^{\circ} \mathrm{C}$ for a prescribed time, and then removing it. The reacted samples were sectioned, and the thickness of the composite layer formed was measured by optical microscopy. There is a $5-10$ min. induction time for Al penetration and reaction with mullite. The rate of ceramic-metal composite formation in the $\mathrm{Al} /$ mullite system is proportional to the square root of time for short reaction times $(<1 \mathrm{hr})$ and is linearly proportional to time for longer reaction times. As expected, composite formation rate also increases with temperature up to $1150^{\circ} \mathrm{C}$ but then exhibits a surprising decrease with increasing temperature between 1150 and $1500^{\circ} \mathrm{C}$. The exact temperature of the maximum rate of composite formation depends on the preform density. Based on the measured penetration distances at given times for different temperatures, an activation energy for composite formation of $\sim 200 \mathrm{~kJ} / \mathrm{mole}$ was calculated. Although the exact mechanism has yet to be determined, the rate controlling step for reactive metal penetration appears to be the interface reaction.

Scanning and transmission electron microscopic analysis of $\mathrm{Al} /$ mullite reaction couples revealed that silicon diffuses out of the mullite ceramic during reactive metal penetration. This observation is also supported by X-ray diffraction analysis and scanning electron microscopy with electron dispersive spectroscopy, which indicated that composites produced by reacting aluminum with mullite are silicon deficient.

In summary, TEM, thermodynamic, and kinetic analyses suggest the following 4-stage reaction mechanism for reactive metal penetration: 1) the metal melts and wets the ceramic preform surface; 2) oxygen diffuses out of the ceramic preform grain boundaries to lower the $\mathrm{PO}_{2}$ to a favorable wetting condition; 3) molten metal penetrates the ceramic preform grain boundaries; and 4) the metal on the grain boundaries reacts with and reduces the individual grains of the ceramic preform.

Impact: By evaluating reactions to understand the mechanisms of composite formation by reactive metal penetration, we are establishing guidelines to control composite formation, and to control the structure and properties of composites formed by reactive metal penetration. These guidelines will be the basis for developing a commercial process for manufacturing ceramic-metal composites with tailored properties.

\section{Task 2. Evaluate Other Ceramic-metal Systems}

As discussed briefly above, the reactions other than $\mathrm{Al} /$ mullite that may produce ceramicmetal composites by reactive metal penetration include: 


$$
\begin{gathered}
\mathrm{Al}_{6} \mathrm{Si}_{2} \mathrm{O}_{13}+3 \mathrm{Mo}+(8+\mathrm{x}) \mathrm{Al} \rightarrow 13 \mathrm{Al}_{2} \mathrm{O}_{3}+3 \mathrm{MoSi}_{2}+\mathrm{xAl} \\
\mathrm{Al}_{6} \mathrm{Si}_{2} \mathrm{O}_{13}+8 \mathrm{Mg} \rightarrow 4 \mathrm{MgO}+2 \mathrm{Mg}_{2} \mathrm{Si}+3 \mathrm{Al}_{2} \mathrm{O}_{3} \\
(4+3 \mathrm{x}) \mathrm{Al}+3 \mathrm{TiO}_{2} \rightarrow 2 \mathrm{Al}_{2} \mathrm{O}_{3}+3 \mathrm{TiAl}_{\mathrm{x}} \\
(2+3 \mathrm{x}) \mathrm{Al}+3 \mathrm{NiO} \rightarrow \mathrm{Al}_{2} \mathrm{O}_{3}+3 \mathrm{NiAl}_{\mathrm{x}}
\end{gathered}
$$

We, as well as others, have proposed that refractory ceramic-metal composites can be synthesized in-situ in the $\mathrm{Al} / \mathrm{TiO}_{2}$ and $\mathrm{Al} / \mathrm{NiO}$ systems according to the reactions listed above. $\mathrm{Ti}$ or $\mathrm{Ni}$ formation is predicted when $\mathrm{x}=0$ in the third and fourth reactions above. For $\mathrm{x}=1$, TiAl or NiAl formation is expected. According to equilibrium thermodynamics, when Al reacts with $\mathrm{TiO}_{2}$ or $\mathrm{NiO}$, the reactions proceed as written above. However, little is known about the kinetics or microstructural mechanisms of the reactions between $\mathrm{Al}$ and either $\mathrm{TiO}_{2}$ or $\mathrm{NiO}$. Likewise, the possibility of using these reactions to form refractory ceramic-metal composites by melt penetration or reactive hot pressing has not been explored in detail.

The contact angle of $\mathrm{Al}$ on $\mathrm{TiO}_{2}$ was determined as a function of temperature. Figure 1 shows that the contact angle decreases as temperature increases from $1000^{\circ} \mathrm{C}$ to $1400^{\circ} \mathrm{C}$. At $1200^{\circ} \mathrm{C}$ the contact angle approaches $90^{\circ}$ while at $1400^{\circ} \mathrm{C}$ it reaches $80^{\circ}$, indicating that aluminum partially wets the ceramic. After an equilibration time of less than 10 minutes, the contact angle varies little with time, indicating no further significant reaction at the interface. Figure 2 shows the cross-section of an $\mathrm{Al}$ drop on $\mathrm{TiO}_{2}$ after heating at $1400^{\circ} \mathrm{C}$ for 75 minutes. No reaction layer was observed for any of the $\mathrm{Al} / \mathrm{TiO}_{2}$ reaction couples, indicating that reactive metal penetration of $\mathrm{TiO}_{2}$ by $\mathrm{Al}$ does not occur under these conditions. Despite not forming a discernible reaction layer, the Al drop strongly adhered to the surface of the substrate. This was true even for contact angles above $90^{\circ}$.

No contact angles were observed for $\mathrm{Al}$ on $\mathrm{NiO}$ because the aluminum did not become fluid enough to form a uniform sessile drop. Apparently, contact with $\mathrm{Al}$ reduced the $\mathrm{NiO}$ substrate, and then, due to reaction with the oxygen liberated during the NiO reduction, a thick, stable oxide layer formed on the Al drop during the wetting experiment. The Al, however, did penetrate and react with the $\mathrm{NiO}$. As shown in Figure 3, an appreciable reaction layer developed during the $1400^{\circ} \mathrm{C}$ contact angle experiment. Samples heated at $1000^{\circ} \mathrm{C}, 1100^{\circ} \mathrm{C}$, and $1200^{\circ} \mathrm{C}$ also showed distinct reaction zones, though penetration depth decreased slightly with decreasing reaction temperature. The reaction layer at the ceramic-metal interface shows that reactive metal penetration is possible in the $\mathrm{Al} / \mathrm{NiO}$ system; however, much more work needs to be done to develop sufficient understanding for process control.

$\mathrm{Al} / \mathrm{TiO}_{2}$ and $\mathrm{Al} / \mathrm{NiO}$ powder mixtures were reactively hot-pressed at $1200-1300^{\circ} \mathrm{C}$ and 34.5 $\mathrm{MPa}$ (5000 psi) for $1 / 2 \mathrm{hr}$ in graphite dies. A compositionally homogeneous, but porous composite of $\mathrm{Al}_{2} \mathrm{O}_{3}$ and $\mathrm{Ti}$ was produced by hot pressing an $\mathrm{Al} / \mathrm{TiO}_{2}$ powder mixture containing $\mathrm{x}=0 \mathrm{Al}$ at $1200^{\circ} \mathrm{C}$. Preliminary results indicate that it may be possible to produce a dense composite with a higher hot-pressing temperature.

A phase-segregated composite consisting of a central metallic core surrounded by a ceramic shell was produced by reactively hot pressing $\mathrm{Al} / \mathrm{NiO}$ powder mixtures containing $\mathrm{x}=0$ and $x=1 \mathrm{Al}$ at $1200^{\circ} \mathrm{C}$ and $1300^{\circ} \mathrm{C}$. X-ray diffraction analysis showed that the metallic core was $\mathrm{Ni}$ and $\mathrm{NiAl}$ for the $\mathrm{x}=0$ and $\mathrm{x}=1$ samples, respectively. The ceramic shell was $\mathrm{Al}_{2} \mathrm{O}_{3}$ in both cases. The phase segregation of the ceramic and metal phases indicates poor wetting of the $\mathrm{Al}_{2} \mathrm{O}_{3}$ by the metallic and intermetallic reaction products. A temperature/pressure program was 
designed to minimize phase segregation and produce a more favorable condition for wetting so that interpenetrating ceramic-metal composite microstructures can form.

The extension of reactive metal penetration and reactive hot pressing to systems that form alumina-intermetallic composites allows for the preparation of novel composites for a variety of high temperature applications. The advantages of these techniques over existing technology include lower raw material and fabrication costs and a finer-scale, interpenetrating microstructure.

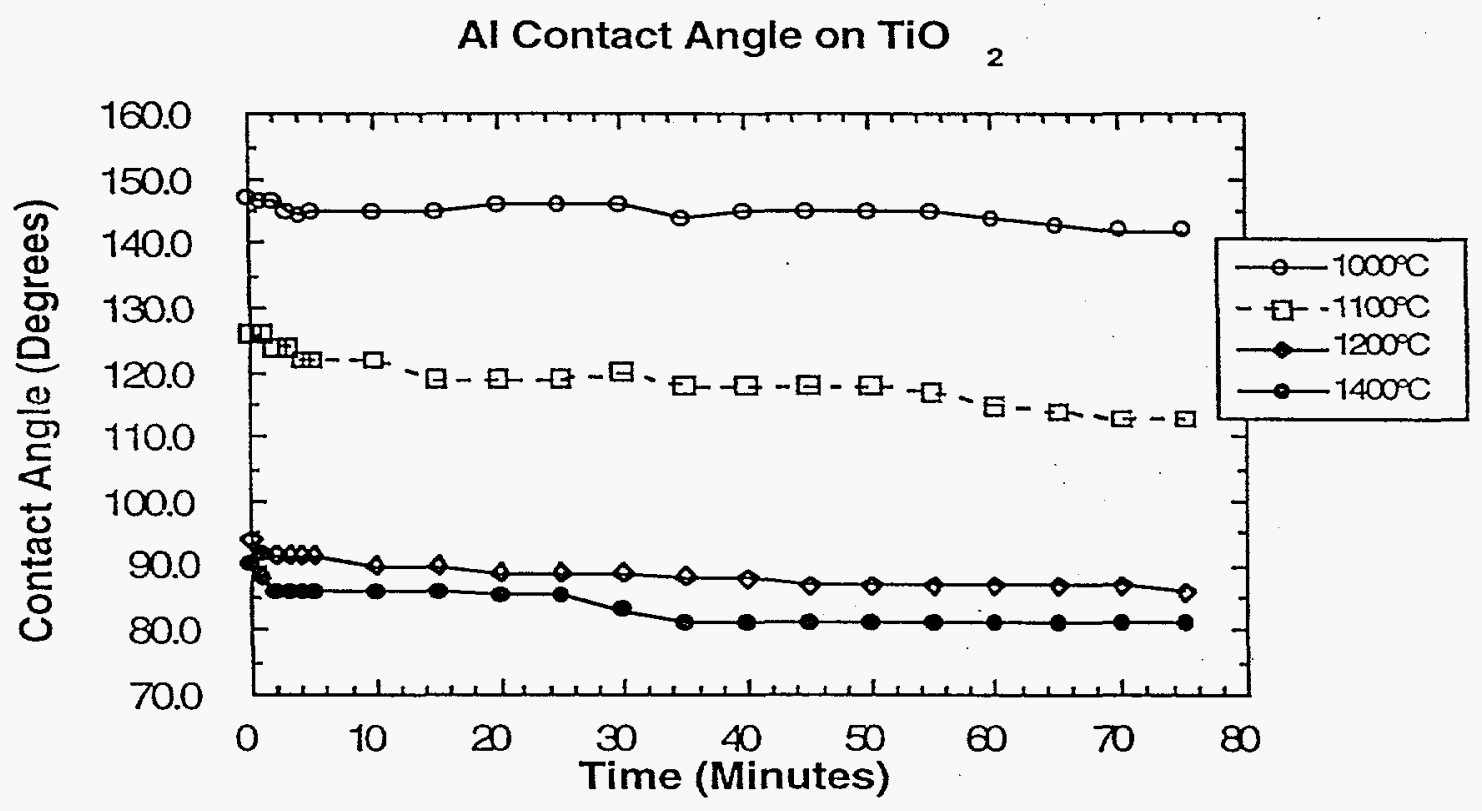

Figure 1. Contact angle as a function of time for $\mathrm{Al}$ in contact with $\mathrm{TiO}_{2}$ at $1000^{\circ} \mathrm{C}, 1100^{\circ} \mathrm{C}$, $1200^{\circ} \mathrm{C}$, and $1400^{\circ} \mathrm{C}$.

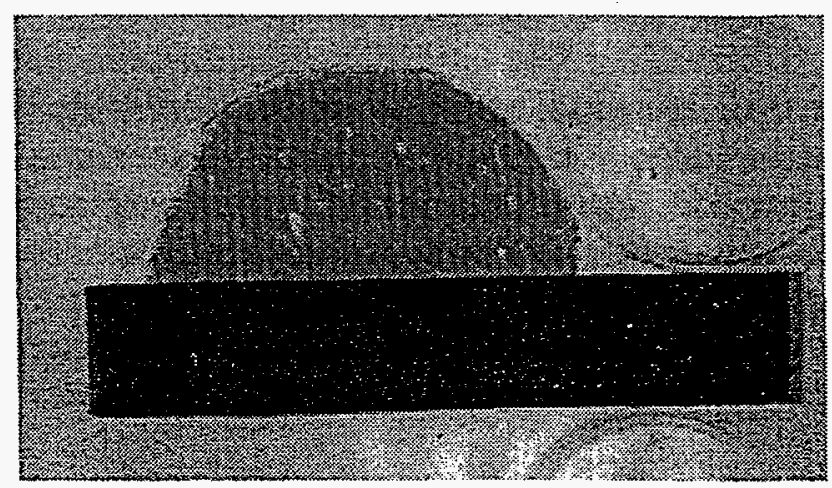

Figure 2. Optical micrograph of the cross-section of an aluminum drop on $\mathrm{TiO}_{2}$ after heat treatment at $1400^{\circ} \mathrm{C}$ for 75 minutes, note the absence of a reaction layer. 


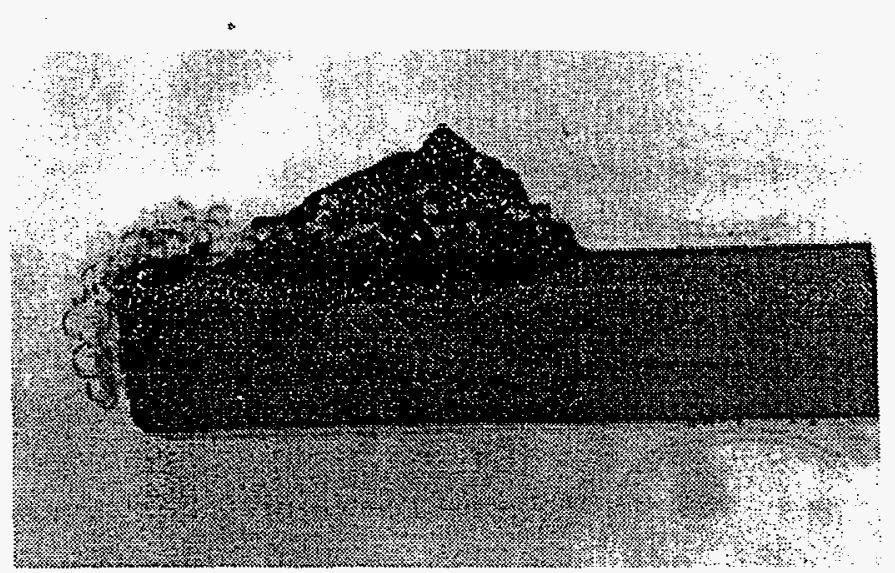

Figure 3. Optical micrograph of the cross-section of an aluminum drop on $\mathrm{NiO}$ after heat treatment at $1400^{\circ} \mathrm{C}$ for 75 minutes, note the presence of a reaction layer.

Cost is perhaps the most important factor in determining the commercial potential of new materials. Advanced composites may offer marked improvement in performance and reliability, but any increase in cost as compared to traditional materials usually prevents significant market penetration. One potential barrier to commercialization that so far has not been addressed in detail in our program is that of raw material cost. Due to the availability, purity, and batch-tobatch consistency of mullite powder as compared to other aluminosilicates, the majority of our work on reactive metal penetration has been carried out using phase-pure mullite preforms. The absence of second phases and trace impurities greatly simplifies the study of reaction mechanism and kinetics as well as the volume and mass balance calculations and thermodynamic predictions. Typically, phase-pure mullite powder sells for $\sim \$ 25 / \mathrm{kg}$. In a previous technical advance, SD5484 at Sandia, we discussed the advantages of using kaolin, $\sim \$ 0.10 / \mathrm{kg}$, as a low-cost alternative to mullite.

As with the $\mathrm{Al} / \mathrm{mullite}$ reaction, initiating the $\mathrm{Al} / \mathrm{kaolin}$ reaction depends on first forming a ceramic-metal interface. Recent results show that aluminum wets dense kaolin better than mullite, as indicated by a reduced contact angle. The lower contact angle should produce a more uniform ceramic-metal interface and, therefore, a more stable reaction front as the metal reacts with and penetrates into the preform. One indication that the $\mathrm{Al} / \mathrm{kaolin}$ reaction is kinetically more favorable is that complex shapes are more easily formed from kaolin preforms as compared to mullite. For porous preforms, aluminum must physically infiltrate the pores prior to reaction with the matrix. In this case, the reduced contact angle in the Al/kaolin system means that physical infiltration of the pores can proceed at much lower temperatures than in the Al/mullite system.

Kaolin, $\mathrm{Al}_{2} \mathrm{Si}_{2} \mathrm{O}_{5}(\mathrm{OH})_{4} \cdot 2 \mathrm{H}_{2} \mathrm{O}$, dehydrates to meta-kaolin, $\mathrm{Al}_{2} \mathrm{Si}_{2} \mathrm{O}_{7}$, when heated to $800^{\circ} \mathrm{C}$. When heated to the sintering temperature, crystalline mullite, $\mathrm{Al}_{6} \mathrm{Si}_{2} \mathrm{O}_{13}$, nucleates and grows within a glassy matrix. A fired kaolin preform is similar to a mullite preform but with a continuous glassy grain boundary phase. The sequential conversion of kaolin to meta-kaolin and then to mullite/silica is detailed in Reactions 3 and 4. 


$$
\begin{gathered}
\mathrm{Al}_{2} \mathrm{Si}_{2} \mathrm{O}_{5}(\mathrm{OH})_{4} \cdot 2 \mathrm{H}_{2} \mathrm{O} \rightarrow \mathrm{Al}_{2} \mathrm{Si}_{2} \mathrm{O}_{7}+4 \mathrm{H}_{2} \mathrm{O} \\
3 \mathrm{Al}_{2} \mathrm{Si}_{2} \mathrm{O}_{7} \rightarrow \mathrm{Al}_{6} \mathrm{Si}_{2} \mathrm{O}_{13}+4 \mathrm{SiO}_{2}
\end{gathered}
$$

Fired kaolin preforms react with aluminum in much the same way as does phase-pure mullite. The reaction is near-net-shape and silicon diffuses away from the reaction front and out of the preform/composite, to produce an $\mathrm{Al}_{2} \mathrm{O}_{3} / \mathrm{Al}$ composite. Due to the higher silica content of the preform, composites prepared from kaolin preforms contain more aluminum than those prepared from mullite. The $\mathrm{Al} / \mathrm{kaolin}$ reaction can be represented as the reaction of aluminum with mullite and silica:

$$
(8+x) \mathrm{Al}+\mathrm{Al}_{6} \mathrm{Si}_{2} \mathrm{O}_{13}+4 \mathrm{SiO}_{2} \rightarrow 7 \mathrm{Al}_{2} \mathrm{O}_{3}+6 \mathrm{Si}+\mathrm{x} \mathrm{Al}
$$

Mass and volume balance equations show that stoichiometric reaction of dense kaolin with aluminum produces a composite that contains approximately 30 vol. $\% \mathrm{Al}$ and 70 vol. $\% \mathrm{Al}_{2} \mathrm{O}_{3}$. This corresponds to an $\mathrm{x}$ value of $\sim 7$ in Reaction 5. The predicted composite density is 3.62 $\mathrm{g} / \mathrm{cm}^{3}$.

As in the $\mathrm{Al} /$ mullite reaction, aluminum reacts with porous kaolin to produce dense ceramic-metal composites through a combination of physical infiltration and reactive penetration. Kaolin preforms fired at $1100^{\circ} \mathrm{C}$ for 3 hours are $\sim 61 \%$ of theoretical density. After reaction with aluminum, the resulting composite contains 56 vol. $\% \mathrm{Al}, 13$ vol. $\% \mathrm{Si}$, and $31 \mathrm{vol} . \% \mathrm{Al}_{2} \mathrm{O}_{3}$. The predicted composite density is $3.05 \mathrm{~g} / \mathrm{cm}^{3}$. The volume and density calculations for reaction of aluminum with dense and porous kaolin are summarized and compared to mullite in Table 2.

Table 2. Al Content and Density of Composites Prepared by Reacting Aluminum with Dense and Porous Mullite and Kaolin.

\begin{tabular}{l|l|l|l|l} 
& Dense Mullite & Porous Mullite & Dense Kaolin & Porous Kaolin \\
\hline Al Content $($ vol.\%) & 17 & 54 & 28 & 56 \\
\hline Density $\left(\mathrm{g} / \mathrm{cm}^{3}\right)$ & 3.75 & 3.15 & 3.62 & 3.05
\end{tabular}

Figures 4 and 5 plot the contact angle of aluminum as a function of temperature on dense and porous kaolin, respectively. As shown in Figure 4, the contact angle for aluminum on dense kaolin generally decreases with increasing time and temperature, except at $1100^{\circ} \mathrm{C}$. At $1100^{\circ} \mathrm{C}$, the aluminum drop rapidly penetrates the preform, indicating a maximum in reaction rate near this temperature. Increased reaction is often accompanied by a decreased contact angle. For aluminum on dense kaolin at $\mathrm{T} \geq 1100^{\circ} \mathrm{C}$, the contact angle is less than $90^{\circ}$, indicating partial wetting. In comparison, the aluminum contact angle on mullite between 1100 and $1400^{\circ} \mathrm{C}$ is around $140^{\circ}$. The implication is that aluminum forms a stable interface more rapidly with kaolin than with mullite. 


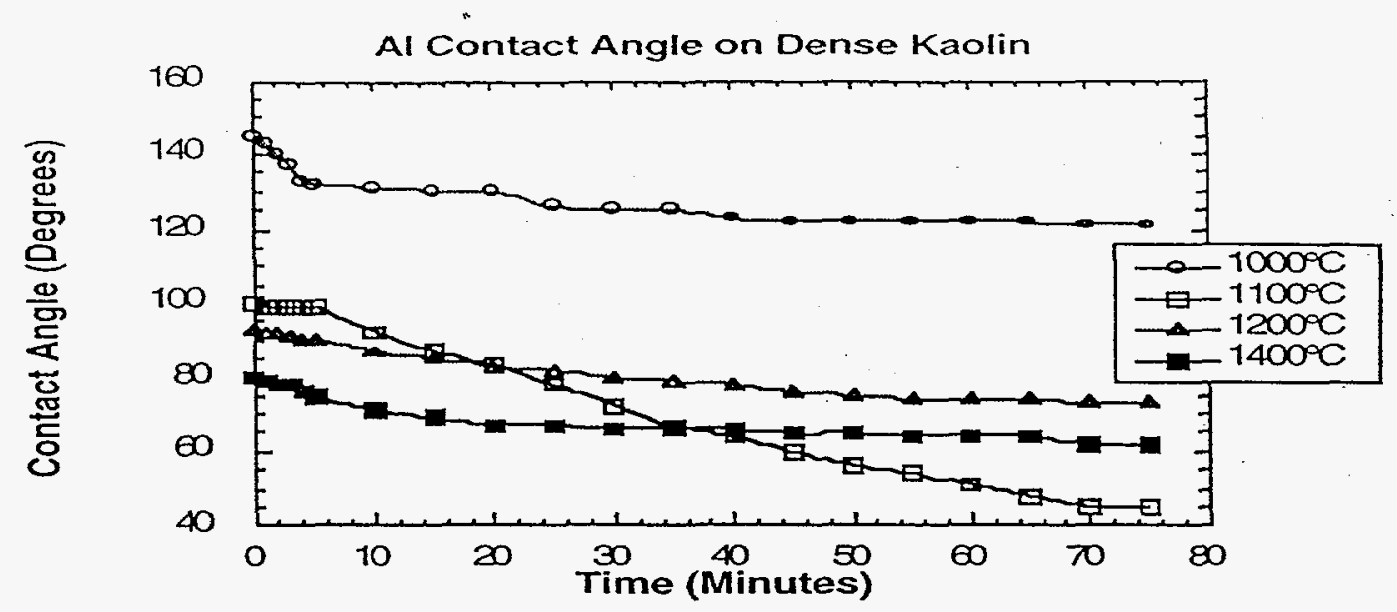

Figure 4. Contact angle of aluminum on dense kaolin.

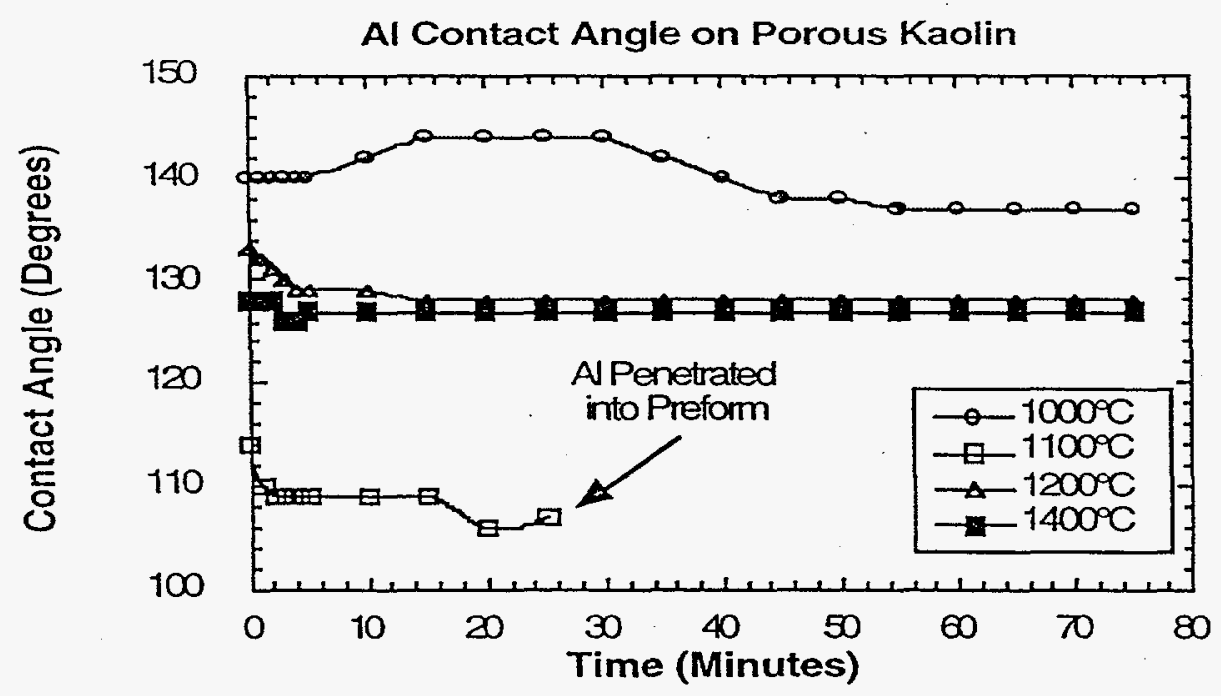

Figure 5. Contact angle of aluminum on kaolin preforms containing 39 vol.\% porosity.

The contact angle of aluminum on kaolin increases with increasing preform porosity. Figure 5 shows that the contact angle of aluminum on kaolin containing 39 vol.\% porosity ( $61 \%$ dense) is significantly higher than on dense kaolin. As with dense kaolin, the contact angle decreases with increasing temperature except at $1100^{\circ} \mathrm{C}$. At $1100^{\circ} \mathrm{C}$, aluminum only partially wets porous kaolin, but it rapidly infiltrates the preform and completely within 30 minutes. For porous mullite, the aluminum contact angle is $\sim 140^{\circ}$ at $1100^{\circ} \mathrm{C}$, with no penetration or reaction. A temperature of at least $1500^{\circ} \mathrm{C}$ is required for aluminum to wet and infiltrate porous mullite. 
The $400^{\circ} \mathrm{C}$ reduction in processing temperature using a kaolin preform will result in significant energy savings during processing, as 'well as a process more favorable for commercialization.

It is curious that wetting and penetration are best at $1100^{\circ} \mathrm{C}$ for both dense and porous kaolin. Generally, contact angle decreases with increasing temperature. The fact that contact angle increases above $1100^{\circ} \mathrm{C}$ for both dense and porous kaolin may be due the formation of a reaction layer between aluminum and kaolin above $1100^{\circ} \mathrm{C}$. Further study is required to determine why $1100^{\circ} \mathrm{C}$ is such a favorable temperature.

Impact: The discovery that kaolin can be used as a raw material may have enormous impact on the commercialization of ceramic-metal composites. Kaolin, the main mineral constituent of common clay, is a low-cost raw material that is available in nearly unlimited quantities. The ceramic industry prepares huge quantities of clay-based products at a nominal cost per piece. In raw material cost alone, there is nearly a three order-of-magnitude savings for kaolin as compared to mullite, with additional savings due to the fact that kaolin is easier to handle, requires fewer organic processing aids, and requires lower firing temperatures. Combined with the ease of conversion from preform to ceramic-metal composite, the low raw material and processing costs suggest that $\mathrm{Al}_{2} \mathrm{O}_{3} / \mathrm{Al}$ composites will be cost-competitive with traditional materials, while offering superior strength and fracture toughness. We are extremely excited about the potential of the $\mathrm{Al} /$ kaolin reaction system and are actively pursuing its development.

Task 3. Assess Near-Net Shape Formation by Reactive Metal Penetration

Reaction of Al with mullite can be written as stated in Reaction 2 in the Summary section. The change in volume, $\Delta V$, on reaction can be calculated from the molar volumes, $V_{m}$, of reactants and products. In the $\mathrm{Al} / \mathrm{mullite}$ system, the relevant values in $\mathrm{cm}^{3} / \mathrm{mol}$ are: $\mathrm{Al}_{6} \mathrm{Si}_{2} \mathrm{O}_{13}(135.26)$, $\mathrm{Al}$ (9.99), $\mathrm{Al}_{2} \mathrm{O}_{3}$ (25.62), and $\mathrm{Si}$ (12.00). For the above reaction, assuming $\mathrm{x}=0$ and a dense mullite preform, the predicted volume change after Al penetration, $\Delta V$, is $-0.72 \mathrm{~cm}^{3} / \mathrm{mole}$. The fractional volume change on reaction, as calculated below, is -0.0018 .

$$
\frac{\Delta V}{3 V_{m}\left(\mathrm{Al}_{6} \mathrm{Si}_{2} \mathrm{O}_{13}\right)}=\frac{13 \mathrm{~V}_{\mathrm{m}}\left(\mathrm{Al}_{2} \mathrm{O}_{3}\right)+6 \mathrm{~V}_{\mathrm{m}}(\mathrm{Si})-3 \mathrm{~V}_{\mathrm{m}}\left(\mathrm{Al}_{6} \mathrm{Si}_{2} \mathrm{O}_{13}\right)}{3 \mathrm{~V}_{\mathrm{m}}\left(\mathrm{Al}_{6} \mathrm{Si}_{2} \mathrm{O}_{13}\right)}=-0.0018
$$

The volume change on reacting $\mathrm{Al}$ with commercial mullite-SiO $\mathrm{S}_{2}$ ceramics can be calculated in a similar way by assuming that the molar volumes of the mullite and silica phases in the preform are additive.

With excess $\mathrm{Al}$ (i.e., $\mathrm{x}>0$ ), reactive metal penetration produces a composite of $\mathrm{Al}_{2} \mathrm{O}_{3}, \mathrm{Al}$, and $\mathrm{Si}$ whose molar volume depends on the $\mathrm{x}$ value in Reaction 2 . Net-shape composites also can be obtained with $x>0$ compositions by adjusting the porosity of the ceramic preform to accommodate the increased volume of $\mathrm{Al}$ present in the composite after reaction. For $\mathrm{x}$ excess moles of $\mathrm{Al}$, the relative density, $\rho_{\mathrm{r}}$, of the mullite preform required for no volume change on reaction is

$$
\frac{3 \mathrm{~V}_{\mathrm{m}}\left(\mathrm{Al}_{6} \mathrm{Si}_{2} \mathrm{O}_{13}\right)}{13 \mathrm{~V}_{\mathrm{m}}\left(\mathrm{Al}_{2} \mathrm{O}_{3}\right)+6 \mathrm{~V}_{\mathrm{m}}(\mathrm{Si})-\mathrm{x} \mathrm{V}_{\mathrm{m}}(\mathrm{Al})}=\frac{40.62}{40.55+\mathrm{x}}
$$


The aluminum content of ceramic-metal composites prepared by reactive metal penetration of dense preforms is controlled by the silica to alumina ratio of the preform. The predicted aluminum content of the composite as a function of the silica content of the preform is given in Figure 6 . This model has been validated by reacting dense aluminosilicate preforms with 28 to $50 \mathrm{wt}$ \% silica and then determining metal content by quantitative stereology and density measurements. Some of the preform compositions tested and their corresponding composite metal contents are shown in Figure 6. By calculation, the upper limit of metal content for reacting a dense silica preform with $\mathrm{Al}$ is $\sim 40$ vol.\%; however, experimentally, 35 vol.\% was found to be the upper limit.

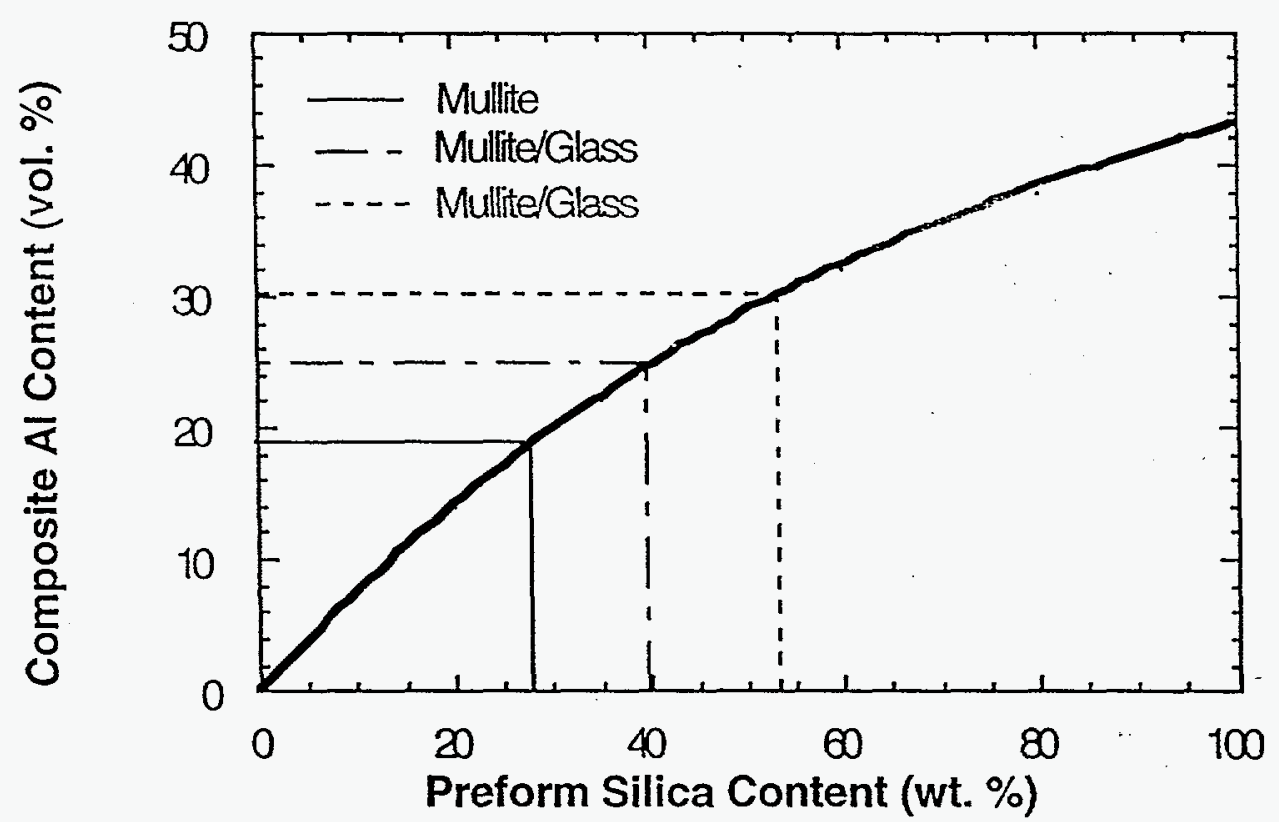

Figure 6. Predicted composite metal content as a function of preform silica content.

Reaction of porous preforms was explored in order to produce composites with higher metal content. Aluminum physically infiltrates the pores of porous mullite preforms and then reacts with the ceramic matrix. The predicted composite metal content increases as the porosity of the preform increases, as shown in Figure 7. This calculation assumes that the reaction is netshape and that the pores are completely filled with metal. The bulk of our experimental work has been carried out with mullite preforms of $62 \%$ relative density, which produce composites that contain 55 vol.\% metal. Examination of composite cross-sections by scanning electron microscopy shows that much of the silicon generated during reaction is retained in the composite. This case contrasts with reactive metal penetration of dense preforms in which the silicon diffuses out of the composite during processing.

Impact: The ability to react porous preforms allows us to prepare ceramic-metal composites with controlled metal content, ranging from near 0 to 55 volume percent. This compositional flexibility 
will allow the design of composites with properties tailored to specific applications. The compositional range demonstrated for reactive metal penetration is far greater than for other reactive forming techniques used to prepare ceramic-metal composites.

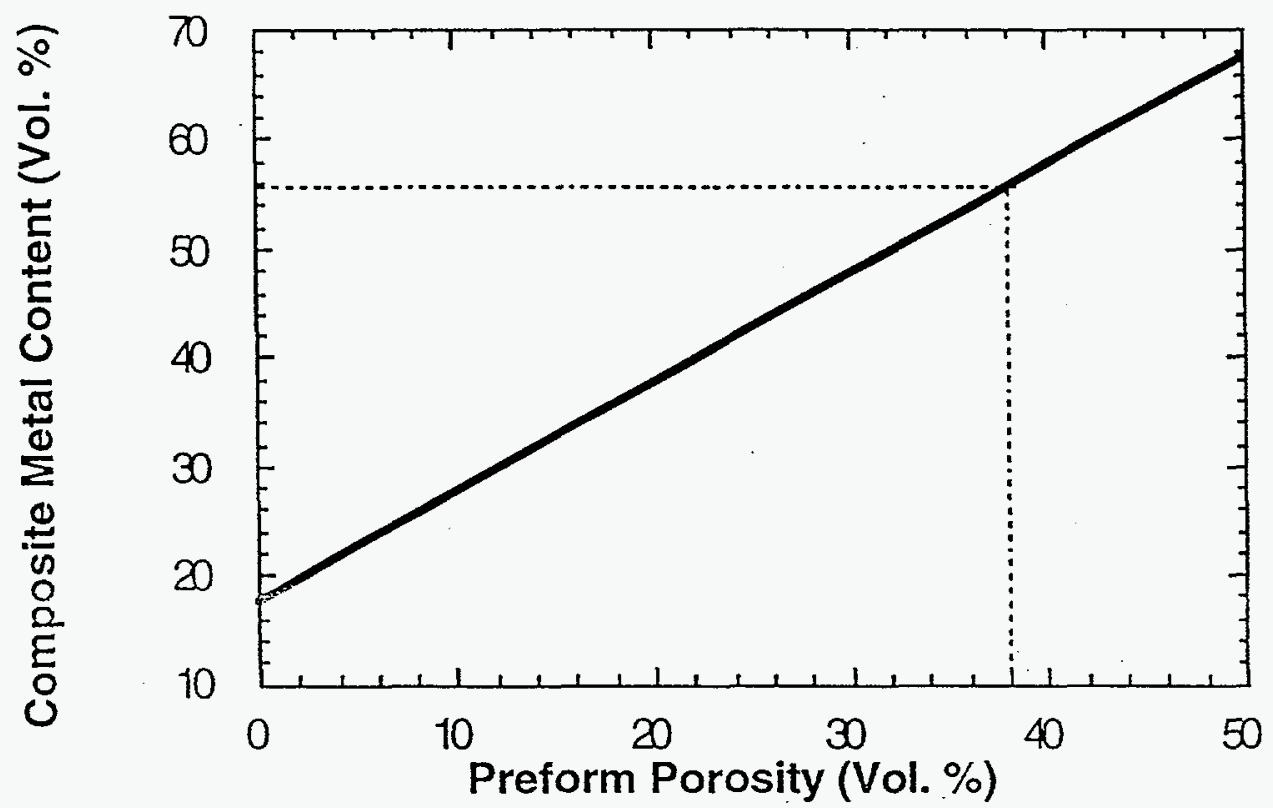

Figure 7. Predicted composite metal content as a function of preform porosity for reaction of aluminum with mullite.

Task 5. Evaluate Ceramic-metal Composite Microstructure and Properties.

The average four-point bend strength for composites with 55 vol. \% metal is $\sim 300 \mathrm{MPa}$, and the Young's modulus is $160 \mathrm{GPa}$. The strengths of these high metal-content composites are comparable to those of other, lower metal-content composites prepared by reactive metal penetration of dense preforms. The strength is impressive for a composite with such a high metal content, and is attributed to the continuous alumina skeleton. The modulus is significantly lower than the lower metal content composites due to the increased size of the metal ligaments. The increased connectivity of the metal phase can be seen when comparing the fracture surface of a composite containing 55 vol.\% metal to one with a lower metal content, as shown in Figure 8 . The metal phase is continuous on the fracture surface of the higher metal content composite whereas isolated metal ligaments are seen in the $25 \mathrm{vol} \%$ metal material. In both microstructures, knife-edging is evident, indicating that the toughness of these composites is enhanced by ductile metal toughening. A toughness as high as $9.0 \pm 1.1$ has been calculated from work of rupture measurements on ceramic-metal composites containing 30 vol.\% Al. Work is in progress to determine more precise toughness values for both types of composite. 


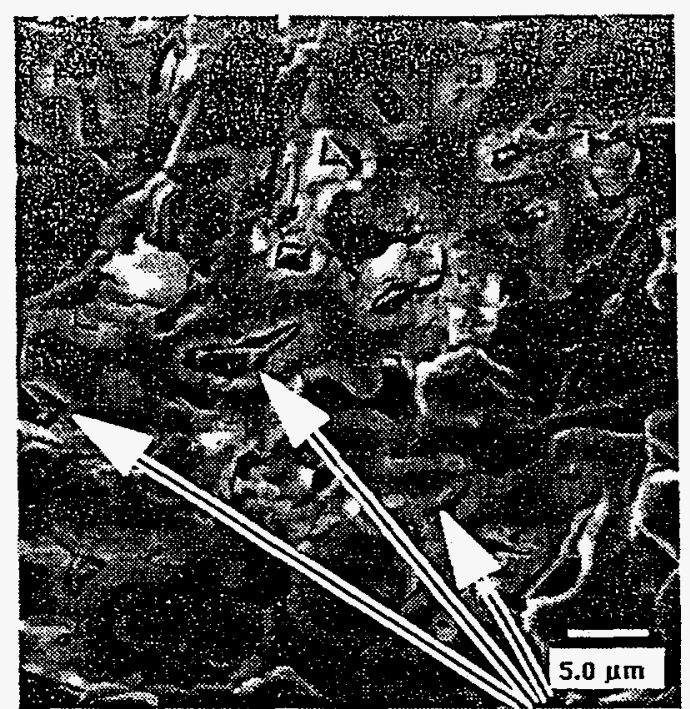

a.

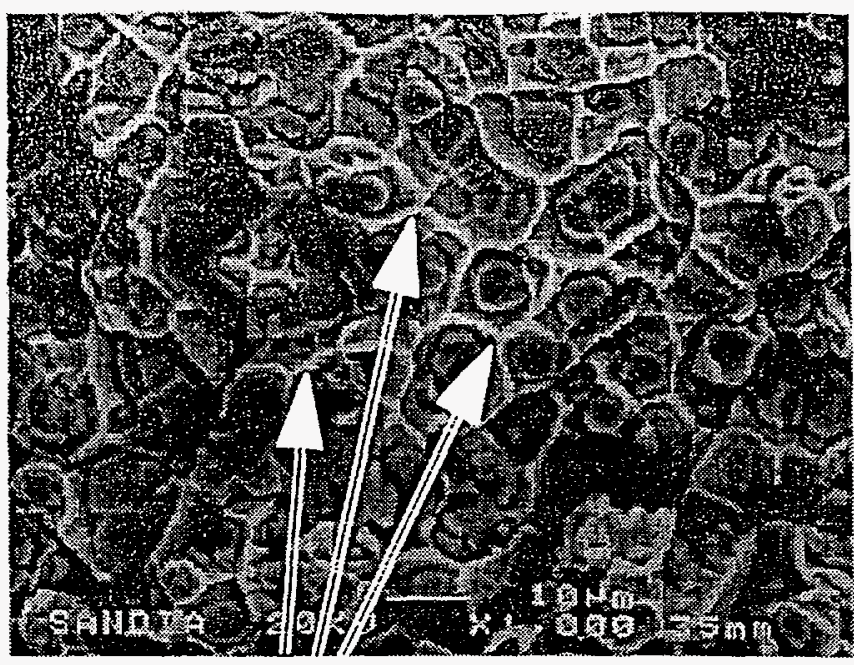

b.

$20 \mu \mathrm{m}$

Figure 8. Fracture surface of ceramic-metal composites containing a) 25 vol. $\%$ and b) 55 vol. $\%$ metal.

The wear properties of a ceramic-metal composite prepared by reactive hot pressing were evaluated by the U.S. Bureau of Mines. The composite was found to have a wear rate of $1.94 \mathrm{x}$ $10^{-3} \mathrm{~mm}^{3} / \mathrm{N} \cdot \mathrm{m}$, which is slightly less than the values for alumina and silicon nitride. Additionally, the reactively-formed ceramic-metal composite exhibits less brittle microfracture on the abraded surface. These are very positive results since many of our proposed applications require good abrasion resistance.

Impact: We have established a property data base for ceramic-metal composites prepared by reactive metal penetration that will be useful for making comparisons to composites formed by other techniques. The property data base also will be useful in demonstrating the versatility of the reactive metal penetration process for making composites for commercial application.

\section{PUBLICATIONS AND PRESENTATIONS (1/1/95 - 12/1/95)}

\section{Journals}

1. Y. Gao, J. Jia, R. E. Loehman, and K. G. Ewsuk, "TEM Studies of Ceramic-metal Composite Fabricated by Reactive Metal Infiltration," J. Matls. Res. 10 [5], (1995).

2. Ronald E. Loehman, Kevin Ewsuk, and Antoni P. Tomsia, "Synthesis of $\mathrm{Al}_{2} \mathrm{O}_{3}-\mathrm{Al}_{1}$ Composites by Reactive Metal Penetration," in press, J. Amer. Ceram. Soc.

3. E. Saiz, A. P. Tomsia, R. E. Loehman, and K. G. Ewsuk, "Formation of $\mathrm{Al}_{2} \mathrm{O}_{3}-\mathrm{Al}$ Composites by Reactive Metal Infiltration of Mullite," in press, Journal of the European Ceramic Society. 
4. W.G. Fahrenholtz, K.G. Ewsuk, R.E. Loehman, and A.P. Tomsia, "Formation of Structural Intermetallics by Reactive Metal Penetration of Ti and Ni Oxides and Aluminates," submitted to Metallurgical and Materials Transactions, March 1995.

5. W. G. Fahrenholtz, K. G. Ewsuk, R. E. Loehman, "Near-Net Shape Processing of Ceramicmetal Composites by Reactive Metal Penetration," submitted for publication, J. Am. Cer. Soc.

6. Kevin G. Ewsuk, S. Jill Glass, Ronald E. Loehman, Antoni P. Tomsia, and William G. Fahrenholtz, "Microstructure and Properties of $\mathrm{Al}_{2} \mathrm{O}_{3}$-Al Composites Formed by In Situ Reaction of Aluminum and Mullite," submitted for publication in Metallurgical and Materials Transactions, April 1995.

7. Y. Gao, J. Jia, R. E. Loehman, K. G. Ewsuk, and W. G. Fahrenholtz "Microstructure and Composition of $\mathrm{Al}_{2} \mathrm{O}_{3}-\mathrm{Al}$ Composites Made by Reactive Metal Penetration," submitted to $J$. Matls. Sci., July 1995.

\section{Proceedings}

1. W.G. Fahrenholtz, K.G. Ewsuk, R.E. Loehman, and A.P. Tomsia, "Synthesis and Processing of $\mathrm{Al}_{2} \mathrm{O}_{3} / \mathrm{Al}$ Composites by In Situ Reaction of Aluminum and Mullite," pp. 99-109 in In-Situ Reactions for Synthesis of Composites, Ceramics, and Intermetallics, ed. by E.V. Barrera, et al., The Minerals, Metals, and Materials Society, Warrendale, PA, 1995.

2. D. Ellerby, W. Scott, R. Bordia, K. Ewsuk, and R. Loehman, "Investigation of the Effect of Microstructure on the R-Curve Behavior of Ceramic-metal Composites," Proc. ICCM-10, Whistler, BC, August 14-18, 1995.

3. Y. Gao, J. Jia, R. E. Loehman, and K. G. Ewsuk, "TEM Characterization of $\mathrm{Al}_{2} \mathrm{O}_{3}-\mathrm{Al}$ Composites Fabricated by Reactive Metal Infiltration," to be published in "Ceramic Matrix. Composites - Advanced High-Temperature Structural Materials," MRS Symp. Proc., Vol. 365, Materials Research Society, Pittsburgh, PA (1995).

\section{Presentations}

1. K.G. Ewsuk, S.J. Glass, R.E. Loehman, W.G. Fahrenholtz, and D.T. Ellerby, "Microstructure and Properties of $\mathrm{Al}_{2} \mathrm{O}_{3} / \mathrm{Al}$ Composites Formed by In Situ Reaction of $\mathrm{Al}$ and

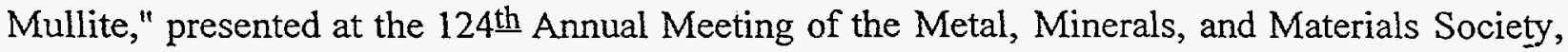
Las Vegas, NV, February 15, 1995.

2. W.G. Fahrenholtz, K.G. Ewsuk, R.E. Loehman, and A.P. Tomsia, "Synthesis and Processing of $\mathrm{Al}_{2} \mathrm{O}_{3} / \mathrm{Al}$ Composites by In Situ Reaction of Aluminum and Mullite," Presented at the 124th Annual Meeting of the Metal, Minerals, and Materials Society, Las Vegas, NV, February 15, 1995. 
3. W. G. Fahrenholtz, S. J. Glass, K. G. Ewsuk, and R. E. Loehman, "Mechanical Properties $\mathrm{Al}_{2} \mathrm{O}_{3} / \mathrm{Al}$ Composites Prepared by Reactive Metal Penetration," presented at the 1995 Annual Meeting of the American Ceramic Society, Cincinnati, OH, April 30 - May 4, 1995.

4. B. P. Hansen, W. G. Fahrenholtz, R. E. Loehman, and K. G. Ewsuk, "Influence of Process Variables on Composition and Microstructure of Reactively Formed Composites," presented at the 1995 Annual Meeting of the American Ceramic Society, Cincinnati, OH, April 30 - May 4, 1995.

5. E. Saiz, A. P. Tomsia, R. E. Loehman, and K. G. Ewsuk, "The Effect of Reactive Penetration of Al Into Porous Mullite," presented at the 1995 Annual Meeting of the American Ceramic Society, Cincinnati, OH, April 30 - May 4, 1995.

6. R. E. Loehman (invited), "Ceramic-Metal Interfaces in Reactively Formed Composites," presented at the 1995 Annual Meeting of the American Ceramic Society, Cincinnati, OH, April 30 - May 4, 1995.

7. R. E. Loehman, K. G. Ewsuk, W. Fahrenholtz, and A. P. Tomsia, "Processing and Properties of $\mathrm{Al}_{2} \mathrm{O}_{3} / \mathrm{Al}$ Composites formed by Reactive Metal Penetration," presented at the DOE/Advanced Materials Concepts Annual Review, Washington, DC, June 15-16, 1995.

8. D. Ellerby, W. Scott, R. Bordia, K. Ewsuk, and R. Loehman, "Investigation of the Effect of Microstructure on the R-Curve Behavior of Ceramic-metal Composites," presented at ICCM-10, Whistler, BC, August 14-18, 1995.

9. K. G. Ewsuk, R. E. Loehman, W. G. Fahrenholtz, and A. P. Tomsia, "Processing Advanced Ceramic-Metal Composites by Reactive Metal Penetration," presented at Sintering 1995, State College, PA, September 24-27, 1995.

10. B. P. Hansen, W. G. Fahrenholtz, R. E. Loehman, and K. G. Ewsuk, "Composite Formation by Reactive Metal Penetration of Mullite Ceramic Preforms with Al Alloys," presented at the 7th Annual New Mexico ACerS/MRS Advanced Materials Symposium, Albuquerque, NM, October 30, 1995.

11. W. G. Fahrenholtz, K. G. Ewsuk, and R. E. Loehman, "Processing and Microstructure of Ceramic-Metal Composites prepared by Reactive Hot Pressing," presented at the 7th Annual New Mexico ACerS/MRS Advanced Materials Symposium, Albuquerque, NM, October 30, 1995.

12. B. B. Lakshman, W. G. Fahrenholtz, K. G. Ewsuk, and R. E. Loehman, "Reactivity and Microstructures at Mg-Ceramic Interfaces," presented at the 7th Annual New Mexico ACerS/MRS Advanced Materials Symposium, Albuquerque, NM, October 30, 1995.

13. W. G. Fahrenholtz, K. G. Ewsuk, R. E. Loehman, "Processing and Properties of ReactivelyFormed Alumina-Metal and Alumina-Intermetallic Composites," to be presented at the 1995 American Ceramic Society Pacific Coast Regional Meeting, Seattle, WA, November 1-3, 1995. 
14. W. G. Fahrenholtz, K. G. Ewsuk, R. E. Loehman, "Processing and Properties of ReactivelyFormed Alumina-Metal and Alumina-Intermetallic Composites," to be presented at the 1995 American Ceramic Society Pacific Coast Regional Meeting, Seattle, WA, November 1-3, 1995.

15. S. J. Glass, K. G. Ewsuk, and W. G. Fahrenholtz, "Mechanical Properties and Reliability of $\mathrm{Al}_{2} \mathrm{O}_{3} / \mathrm{Al}$ Composites Formed By Reactive Metal Penetration," to be presented at the 1995 American Ceramic Society Pacific Coast Regional Meeting, Seattle, WA, November 1-3, 1995.

16. D. Ellerby, W. Scott, R. Bordia, K. Ewsuk, and R. Loehman, "Investigation of the Effect of Microstructure on the R-Curve Behavior of Ceramic-metal Composites," presented at the 1995 American Ceramic Society Pacific Coast Regional Meeting, Seattle, WA, November 1-3, 1995.

17. K. G. Ewsuk, W. G. Fahrenholtz, R. E. Loehman, and A. P. Tomsia, "A Comparison of Reactive Processes for Forming Ceramic-Metal Composites," to be presented at the 1995 American Ceramic Society Pacific Coast Regional Meeting, Seattle, WA, November 1-3, 1995.

18. E. Saiz, A. P. Tomsia, R. E. Loehman, and K. G. Ewsuk, "Al-Al2 $\mathrm{O}_{3}$ Composite Formation by Reactive Penetration of Different Silicon-Based Ceramics," to be presented at the 1995 American Ceramic Society Pacific Coast Regional Meeting, Seattle; WA, November 1-3, 1995.

19. B. B. Lakshman, W. G. Fahrenholtz, A. P. Tomsia, K. G. Ewsuk, and R. E. Loehman, "Synthesis, Composition, and Microstructures of Composites Made by Reactive Penetration of Ceramics by $\mathrm{Mg}$," presented at the American Ceramic Society Basic Science Division Meeting, New Orleans, LA, November 5-8, 1995.

HONORS AND AWARDS

None this reporting period

\section{PATENTS/DISCLOSURES}

None this reporting period

\section{LICENSES}

None this reporting period

\section{INDUSTRIAL INPUT, TECHNOLOGY TRANSFER, AND OTHER INTERACTIONS}

\section{Collaboration with other researchers}

We are continuing our collaboration with A.P. Tomsia of Pask Research and Engineering. Dr. Tomsia is the co-discoverer of reactive metal penetration and is contributing significantly to 
its understanding and development. Dr. Eduardo Saiz is a visiting scientist working with Dr. Tomsia on the project, supported by Pask Research and Engineering. Dr. Y. Gao of Pacific Northwest Laboratories has continued to collaborate on TEM analysis of composites formed by reactive metal penetration. Professor Ping $\mathrm{Lu}$ of $\mathrm{New}$ Mexico Institute of Mining and Technology is also providing TEM analysis of reaction zones, supported on a subcontract to the project. Bala Lakshman is a graduate student at the University of New Mexico who is doing a Master's thesis on reactive metal penetration under the direction of Dr. Ronald Loehman. Professor Raj Bordia of the University of Washington provided a graduate student to work on the project during the summer of 1995 at the Advanced Materials Laboratory and throughout the year at U. WA. One of UT (El Paso) Professor Art Bronson's graduate students is working on the project as a co-op student for his MS thesis. We also continued our collaboration with researchers at the U.S. Bureau of Mines to study the wear properties of ceramic-metal composites made by reactive metal penetration. Additionally, John Kaniuk Of Zircoa, Inc. Conducted corrosion tests this year on some of our high metal content composites.

\section{COST-SHARING}

Pask Research and Engineering is contributing significant research output at no cost to the project. Pask R\&E values their contributions at $-\$ 40,000$ in direct salary costs for the staff time devoted to the project. Graduate students working on the project with support from their home institutions (U. WA and UT, El Paso) accounted for an additional $~ \$ 50,000$ of support for the program. Work conducted at the U.S. Bureau of Mines has an estimated value (in direct salary costs) of $\sim \$ 10,000$.

\section{HIGHLIGHTS}

The discovery that kaolin can be used as a raw material for the preparation of ceramic-metal composites may have enormous impact on the commercialization of such materials. Kaolin, the main mineral constituent of common clay, is a low-cost raw material that is available in nearly unlimited quantities. In raw material cost alone, there is nearly a three order-of-magnitude savings for kaolin as compared to mullite, with additional savings from the fact that kaolin is easier to handle, requires fewer organic processing aids, and requires lower firing temperatures. The reaction of $\mathrm{Al}$ with kaolin is similar to that with mullite, except that kaolin has a higher silica content, which is reflected in the reaction product:

$(8+\mathrm{x}) \mathrm{Al}+\mathrm{Al}_{6} \mathrm{Si}_{2} \mathrm{O}_{13}+4 \mathrm{SiO}_{2} \rightarrow 7 \mathrm{Al}_{2} \mathrm{O}_{3}+6 \mathrm{Si}+\mathrm{x} \mathrm{Al}$. Thus, kaolin can produce composites with higher $\mathrm{Al}$ contents than does mullite, which extends the range of available metal contents using dense preforms. The ease of conversion from preform to ceramic-metal composite and the lower raw material and processing costs using kaolin suggest that $\mathrm{Al} / \mathrm{Al}_{2} \mathrm{O}_{3}$ composites will be cost-competitive with traditional materials, while offering superior strength and fracture toughness. 


\section{Significant Accomplishment}

\section{Reactive Penetration Process Produces Ceramic-Metal Composites to Net- Shape Using Low-Cost Raw Materials}

\section{Problem}

Ceramic-metal composites are candidate materials for advanced structures and components because of their high stiffness-to-weight ratios and excellent fracture toughness. However, their raw materials costs can be high and they generally are expensive to make in finished shapes.

Results:

Reactive metal penetration, the process by which a reactive metal penetrates a dense ceramic preform and converts it to a ceramic-metal composite, appears to be an inherently net-shape process. In the $\mathrm{Al} /$ mullite system the molar volumes of reactants and products are such that the stoichiometric reaction exhibits no net change in volume. However, even off-stoichiometry reactions are found to have less than a $2 \%$ volume change from reactants to products. The reason seems to be a reaction mechanism in which the dense ceramic preform maintains the overall shape of the part while the reaction proceeds.

Recently it was discovered that kaolin can be used as the ceramic preform for these reactivelyformed composites. The reaction of $\mathrm{Al}$ with kaolin is similar to that with mullite, except that kaolin has a higher silica content, which is reflected in the reaction product:

$(8+x) \mathrm{Al}+\mathrm{Al}_{6} \mathrm{Si}_{2} \mathrm{O}_{13}+4 \mathrm{SiO}_{2} \rightarrow 7 \mathrm{Al}_{2} \mathrm{O}_{3}+6 \mathrm{Si}+\mathrm{x} \mathrm{Al}$. Wetting and penetration of kaolin by $\mathrm{Al}$ is as favorable as with mullite. Kaolin can produce composites with higher $\mathrm{Al}$ contents than does mullite, which extends the range of available metal contents using dense preforms.

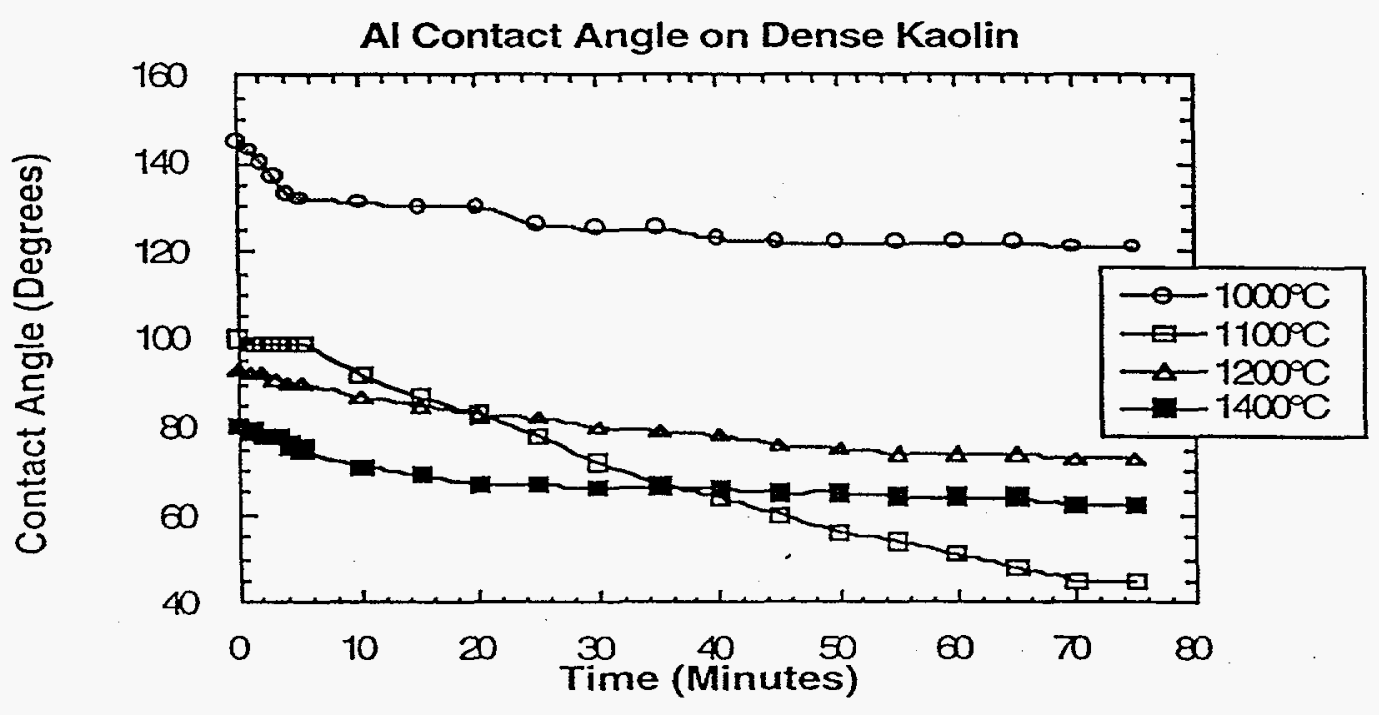

Contact angle of aluminum on dense kaolin. 


\section{Significance}

The discovery that kaolin can be used as a raw material for the preparation of ceramic-metal composites may have enormous impact on the commercialization of such materials. Kaolin, the main mineral constituent of common clay, is a low-cost raw material that is available in nearly unlimited quantities. In raw material cost alone, there is nearly a three order-of-magnitude savings for kaolin as compared to mullite, with additional savings due to the fact that kaolin is easier to handle, requires fewer organic processing aids, and requires lower firing temperatures. than does mullite, which extends the range of available metal contents using dense preforms. (R\&D performed at Sandia National Laboratories under DOE-CE-AIM support.) 


\section{Project Summary}

\section{ADVANCED INDUSTRIAL CONCEPTS (AIC) MATERIALS PROGRAM}

WORK ELEMENT: Advanced Ceramics and Composites

PROJECT TITLE: Synthesis and Processing of Composites by Reactive Metal Penetration PHASE: FY 1995

PERFORMING ORGANIZATION: Sandia National Laboratories

PRINCIPAL INVESTIGATORS: Ronald E. Loehman (505) 272-7601 and Kevin G. Ewsuk (505) 272-7620

PHASE OBJECTIVES: The objectives for this year were to use results of wetting and TEM experiments to refine our model for the reactive penetration mechanism; to investigate the potential for using kaolin as an inexpensive ceramic precursor material; to investigate reactive penetration of $\mathrm{NiO}$ and $\mathrm{TiO}_{2}$ ceramics; and to demonstrate net-shape forming using porous ceramic preforms that produce a wider range of composite metal contents.

ULTIMATE OBJECTIVE: The overall objectives of the program are: 1) to identify compositions favorable for making composites by reactive metal penetration; 2) to determine the mechanisms that control the process; and 3) to optimize the process so that composites and composite coatings with commercial potential can be made.

TECHNICAL APPROACH: Composites are made by reacting molten metals with ceramics under controlled conditions. Cross sections of reaction fronts are examined by $\mathrm{x}$-ray and electron analytical techniques to identify compositions and microstructures. Those results are compared with data from wetting and penetration experiments using the sessile drop technique and are analyzed using thermodynamic calculations and phase diagram data. We use those results to make test specimens for determining composite physical properties.

PROGRESS: We have made ceramic composites of $\mathrm{Al}_{2} \mathrm{O}_{3} / \mathrm{Ti}_{3} \mathrm{Al}$ and $\mathrm{Al}_{2} \mathrm{O}_{3} / \mathrm{Ni}_{3} \mathrm{Al}$ by reactive hot-pressing. We discovered that kaolin can serve as a low-cost ceramic preform for making $\mathrm{Al}_{2} \mathrm{O}_{3} / \mathrm{Al}$ composites to near-net-shape. We learned how to improve the pressureless infiltration of molten $\mathrm{Al}$ into porous mullite and kaolin, which allows us to obtain composites with a much wider range of metal concentrations than when using dense ceramic preforms.

Patents:

Books:
Publications: 7

Presentations: 19
Proceedings: 3 
PROJECT TITLE: Synthesis and Processing of Composites by Reactive Metal Penctration

CRITICAL ISSUES: The potential market for advanced ceramic-metal composites is as substitutes for existing materials. Even though their properties may be substantially better than existing materials, experience has taught us that the advanced materials are unlikely to penetrate commercial markets unless their cost is competitive with what is in current use. Because advanced materials by their nature are new, they generally lack a design history and data base on properties and reliability sufficient to persuade designers to specify the new material. Thus, the critical issues for any new material are reliability and cost. Ceramic-metal composites made by reactive metal penetration are no exception.

POTENTIAL PAYOFF: Wider use of ceramic-metal composites requires improvements in synthesis and processing so that high-performance parts can be produced more economically. Reactive metal penetration produces ceramic-metal composites that exhibit high stiffness-toweight ratios, good fracture toughness, and their electrical and thermal properties can be varied through control of their compositions and microstructures. We are learning that reactive metal penetration could be an economical process for manufacturing many of the advanced ceramic composites that are needed for light-weight structural and wear applications. Near-net-shape fabrication of parts has the additional advantage that costly and energy intensive grinding and machining operations are significantly reduced, and the waste generated from such finishing operations is minimized. 